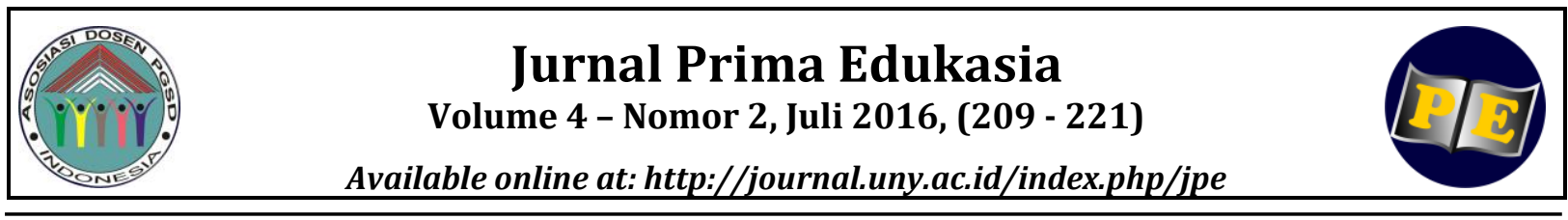

\title{
PENGEMBANGAN VIDEO PEMBELAJARAN UNTUK MENINGKATKAN MOTIVASI DAN HASIL BELAJAR KOGNITIF SISWA KELAS IV SD
}

\author{
Titi Suryansyah $^{1)}$, Suwarjo ${ }^{2)}$ \\ ${ }^{1}$ SD Negeri Jetis. Pacarejo, Semanu, Gunungkidul, Daerah Istimewa Yogyakarta, Indonesia \\ ${ }^{2}$ Psikologi Pendidikan dan Bimbingan, Universitas Negeri Yogyakarta. Jalan Colombo No.1 \\ Karangmalang, Yogyakarta 55281, Indonesia. \\ Email: ${ }^{1}$ titipjj_16@yahoo.co.id, ${ }^{2}$ suwarjo@uny.ac.id
}

\begin{abstract}
Abstrak
Penelitian ini bertujuan untuk menghasilkan media video pembelajaran yang layak dan efektif dalam meningkatkan motivasi dan hasil belajar kognitif bagi siswa kelas IV SD Gugus Pacarejo, Kecamatan Semanu, Gunungkidul. Penelitian ini menggunakan langkah pengembangan menurut Borg \& Gall, tetapi desain pengembangan media video pembelajaran ini hanya meliputi 9 langkah, yaitu (1) studi pendahuluan, (2) perencanaan, (3) pengembangan produk awal, (4) uji coba awal, (5) revisi produk awal, (6) uji coba lapangan, (7) revisi produk hasil uji coba lapangan, (8) uji coba lapangan operasional, dan (9) revisi produk akhir. Hasil penelitian menunjukkan bahwa media video pembelajaran layak digunakan menurut ahli materi dan ahli media dengan kategori "baik". Produk yang dikembangkan juga terbukti efektif meningkatkan motivasi dan hasil belajar kognitif siswa kelas IV SD Gugus Pacarejo. Rata-rata skor motivasi dan nilai hasil belajar kognitif pada kelas eksperimen lebih tinggi daripada kelas kontrol.
\end{abstract}

Kata Kunci: media video pembelajaran, motivasi belajar, hasil belajar kognitif

\section{DEVELOPING INSTRUCTIONAL VIDEO TO ENHANCE THE MOTIVATION AND LEARNING OUTCOMES OF $4^{\text {th }}$ GRADE STUDENTS}

\begin{abstract}
This research aims to produce an instructional video media that is feasible and effective for increasing the motivation and cognitive learning outcomes of $4^{\text {th }}$ grade students of SD Gugus Pacarejo, Kecamatan Semanu, Gunungkidul. This research is a research and development study from Borg \& Gall model, but the design of an instructional video media consists of only nine steps, including (1) preliminary study, (2) planning, (3) preliminary product development, (4) preliminary field testing, (5) main product revision, (6) main field testing, (7) operational product revision, (8) operational field testing, (9) final product revision.The results are as follows the developed instructional video media is fit use according to the media expert and material expert, which is in a good category. The developed instructional video media is effective for increasing the motivation and learning outcome of the $4^{\text {th }}$ grade students of SD Gugus Pacarejo. The average score of motivation and the value of the cognitive learning in the experimental class which is higher than that of the control class.
\end{abstract}

Keywords: instructional video media, learning motivation, cognitive learning outcomes

How to Cite: Suryansah, T., \& Suwarjo, S. (2016). Pengembangan video pembelajaran untuk meningkatkan motivasi dan hasil belajar kognitif siswa kelas IV SD. Jurnal Prima Edukasia, 4(2), 209-221. doi:http://dx.doi.org/10.21831/jpe.v4i2.8393

Permalink/DOI: http://dx.doi.org/10.21831/jpe.v4i2.8393 
Jurnal Prima Edukasia, 4 (2), Juli 2016 - 210

Titi Suryansyah, Suwarjo

\section{Pendahuluan}

Pendidikan memiliki peran penting dalam mencerdaskan kehidupan bangsa. Guru sebagai pelaku utama proses pendidikan menjadi salah satu penentu terciptanya pendidikan yang berkualitas. Beberapa peran guru yakni sebagai pendidik, pengajar, fasilitator, dan inovator. Dalam menjalankan perannya, guru dituntut untuk mampu memilih metode serta merancang kegiatan pembelajaran yang mengaktifkan siswa, menyediakan sumber belajar yang variatif, dan memilih media pembelajaran yang memungkinkan siswa mudah dalam menyerap informasi serta mampu menumbuhkan motivasi belajar siswa.

Motivasi menjadi hal penting dalam melakukan suatu kegiatan, khususnya dalam pembelajaran. Motivasi harus terus ditumbuhkan dalam diri siswa sebagai modal dasar untuk mecapai tujuan belajarnya. Seorang guru harus mau berinovasi dalam setiap pembelajaran guna menumbuhkan motivasi belajar siswa. Motivasi akan mampu memberikan kekuatan tersendiri bagi siswa. Motivasi belajar bisa dikatakan sebagai suatu proses yang memberi semangat, arah, dan kegigihan perilaku (Santrock, 2011, p. 510). Berdasarkan pengertian tersebut, siswa yang memiliki motivasi berarti tidak akan mudah menyerah dan akan terus berusaha sampai terwujud apa yang diinginkan. Motivasi belajar yang sudah terpatri dalam diri siswa mampu mengarahkan siswa menjadi pribadi yang tangguh. Motivasi belajar menjadi salah satu kunci meraih keberhasilan siswa.

Keberhasilan siswa dalam belajar bisa diwujudkan dalam bentuk prestasi atau hasil belajar yang tinggi. Hal tersebut sesuai dalam Schunk (2012, p. 80) bahwa tindakan-tindakan yang dilandasi motivasi meliputi pilihan atas tugas-tugas, upaya (fisik dan mental), ketekunan, dan prestasi. Oleh sebab itu, untuk mewujudkan siswa yang berprestasi diperlukan dukungan dari berbagai pihak, baik itu keluarga, sekolah, masyarakat, dan pemerintah. Sejalan dengan itu, menurut Sonmez \& Can (2012, p. 141) menyampaikan bahwa "student teaching is an integral part of teacher education". Dari pernyataan tersebut dapat diartikan bahwa pembelajaran siswa menjadi bagian tak terpisahkan dari pendidikan guru. Guru sebagai orang tua dan teman selama di sekolah perlu menciptakan proses pembelajaran yang mampu mendukung terwujudnya siswa yang berprestasi. Hasil belajar yang baik diharapkan mampu mengantarkan siswa meraih citacitanya.

Hasil belajar siswa khususnya dalam aspek kognitif meliputi semua mata pelajaran yang dipelajari di Sekolah Dasar (SD). Ilmu Pengetahuan Sosial (IPS) merupakan salah satu mata pelajaran yang dipelajari di SD yang memiliki cakupan materi sangat luas. Keluasan materi IPS tidak diimbangi oleh jumlah jam belajar pada tiap minggunya yaitu hanya 3 jam pelajaran. Hal tersebut menjadi tantangan bagi setiap guru untuk mampu mengefektifkan setiap pembelajarannya supaya materi dapat tersampaikan dengan baik. Aktivitas ekonomi dan potensi alam menjadi bagian materi dalam pembelajaran IPS di SD. Kondisi wilayah di Indonesia yang sangat luas berpengaruh terhadap keberagaman potensi alam. Potensi alam yang ada di setiap daerah akan berpengaruh terhadap aktivitas ekonomi di masing-masing daerah. Aktivitas ekonomi berdasarkan potensi alam di daerah siswa tentu sudah diketahui siswa, namun untuk mengenalkan aktivitas ekonomi berdasarkan potensi alam di daerah lain diperlukan gambaran yang jelas. Guru bisa memanfaatkan media pembelajaran yang dapat menampilkan kondisi lingkungan sehingga mempermudah penyampaian materi pembelajaran. Pernyataan tersebut senada dengan yang disampaikan oleh Muvawala (2012, p. 42) "Evidence from the study also indicates that investing in software inputs has a higher positive impact on learning outcomes than do hardware educational inputs". Muvawala menyatakan bahwa hasil belajar bisa ditingkatkan dengan memanfaatkan perangkat lunak dalam pembelajarannya. Perangkat lunak yang dimaksud bisa diwujudkan dalam bentuk media pembelajaran berbasis teknologi.

Penggunaan media diharapkan dapat mengoptimalkan kegiatan pembelajaran. Kemenarikan dari suatu media mampu menjadi daya tarik dari media itu sendiri. Pemanfaatan media dalam belajar dapat membantu meningkatkan konsentrasi siswa. Senada dengan hal tersebut, Astuti \& Mustadi (2014, p. 250) menyatakan bahwa media pembelajaran berupa film animasi dapat memberikan pengaruh positif terhadap kemampuan bahasa siswa. Selain itu, media dalam pembelajaran bisa membantu siswa memahami materi lebih cepat dan lebih baik, sehingga pengetahuan yang diperoleh akan bertahan lama. Hal tersebut senada dengan pendapat dari Woo (2014, p. 303) menyatakan bahwa "based on the research results, when designing digital 
game based learning (a media), designers should increase motivation and germane cognitive load to enhance learning effectiveness". Pernyataan tersebut memberikan pesan akan pentingnya merancang suatu bentuk media yang dapat meningkatkan motivasi dan aspek kognitif siswa dalam belajar. Media pembelajaran selalu mengalami perkembangan dari waktu ke waktu. Ini menjadi tantangan bagi guru untuk selalu melakukan inovasi dalam pembelajaran. Seorang guru diharapkan mampu merancang media pembelajaran yang bisa memberikan pengaruh positif kepada siswa.

Kemajuan teknologi dan informasi memungkinkan guru memilih berbagai media yang mendukung penyampaian materi. Hal tersebut senada dengan yang disampaikan oleh Li \& Shieh (2016, p. 161) "The development of global education in past years presents plural, innovative, and open new atmosphere, mainly because of changeable technologies and rapid boom of knowledge". Sehubungan dengan hal tersebut, guru dituntut untuk menguasai teknologi guna memberikan kemudahan kepada siswa dalam belajar. Guru bisa menggunakan jenis media audio visual yang mampu memberikan kejelasan terhadap suatu materi yang dipelajari. Jenis media audio visual bisa berupa video pembelajaran. Pengambilan objek dalam video bisa disesuaikan dengan karakteristik siswa. Banyak kelebihan pemanfaatan video dalam pembelajaran, salah satunya seperti yang disampaikan oleh Bavarharji, Alavi, dan Letchumanan (2014, p. 1) bahwa "The results showed that the effects of viewing captioned instructional videos are greater on vocabulary acquisition and language proficiency development than on content comprehension". Dari pernyataan tersebut dapat dinyatakan bahwa pemanfaatan video dapat meningkatkan kemampuan bahasa siswa. Dari penguasaan bahasa yang meningkat tentu akan mempermudah siswa dalam memahami materi yang disampaikan.

Siswa SD lebih banyak belajar melalui interaksi dengan lingkungan sekitar. Pemilihan media pembelajaran akan lebih bermakna bagi siswa jika dilengkapi dengan materi, ilustrasi, gambaran nyata yang diadopsi dari lingkungan siswa. Guru bisa mengembangkan dari lingkungan terdekat siswa sampai dengan lingkungan yang jauh dari siswa. Guru juga bisa memadukan antara teknologi dengan lingkungan menjadi sebuah media video yang menarik sehingga mampu meningkatkan motivasi belajar siswa serta meningkatkan pemahamannya. Pernyataan tersebut sependapat dengan Yoon \& Kim (2011, p. 284) "students are more likely to be motivated to learn if they expect that they are going to be taught something interesting or important". Pemanfaatan media pembelajaran yang tepat mampu memberikan semangat tersendiri bagi siswa untuk belajar. Pemanfaatan media pembelajaran yang menarik dapat menciptakan pembelajaran yang menyenangkan sehingga tujuan pembelajaran akan mudah dicapai. Hal tersebut senada dengan pernyataan Indaryati \& Jailani (2015, p.88) proses pembelajaran yang menyenangkan dapat memudahkan siswa dalam meningkatkan motivasi belajarnya dan prestasi belajar khususnya aspek kognitif. Meskipun demikian, pernyataan tersebut berbeda jauh dengan apa yang terjadi di Gugus Pacarejo.

Berdasarkan hasil wawancara dengan guru kelas IV di Gugus Pacarejo pada bulan Juni 2015 disimpulkan bahwa guru memerlukan sebuah media pembelajaran karena media yang tersedia di sekolah belum lengkap. Guru mengungkapkan bahwa masih mengalami kesulitan dalam mengembangkan media pembelajaran padahal komputer atau laptop sudah tersedia. Fasilitas yang tersedia di hampir tiap sekolah, belum bisa dimanfaatkan secara optimal. Laptop dan Liquid Crystal Display (LCD) masih jarang dimanfaatkan saat pembelajaran. Hal tersebut patut disayangkan mengingat pemerintah telah memberikan banyak fasilitas guna meningkatkan kualitas pendidikan. Pemerintah telah mengeluarkan banyak anggaran di bidang pendidikan guna mewujudkannya. Selain diwujudkan dalam bentuk fasilitas pembelajaran, pemerintah juga memberikan pelatihan kepada para tenaga pengajar guna meningkatkan kemampuan mengajarnya. Pelatihan dalam bidang teknologi juga sering diadakan dengan harapan mampu memberikan pelayanan yang terbaik kepada anak didik.

Hasil analisis produk yang sudah ada diketahui bahwa video pembelajaran materi aktivitas ekonomi berdasarkan potensi alam masih bersifat umum. Video yang ditampilkan adalah aktivitas ekonomi di berbagai wilayah di Indonesia, padahal sesuai Standar Kompetensi IPS di kelas IV disesuaikan dengan wilayah siswa. Karena Gugus Pacarejo berada di wilayah Kabupaten Gunungkidul, Daerah Istimewa Yogyakarta, maka diperlukan media video yang menampilkan kondisi wilayah Yogyakarta. 
Jurnal Prima Edukasia, 4 (2), Juli 2016 - 212

Titi Suryansyah, Suwarjo

Berdasarkan observasi di kelas IV dapat diketahui beberapa hal sehubungan dengan kegiatan pembelajaran siswa. Pada saat melakukan pembelajaran IPS guru hanya menggunakan media pada umumnya, seperti peta, globe, dan gambar. Gambar yang digunakan hanya sebatas yang ada di buku teks. Gambar tersebut hanya berwarna hitam putih, sehingga terlihat kurang menarik. Padahal bisa kita ketahui bahwa di internet kita bisa dengan mudah mendapatkan gambar-gambar dengan warna yang menarik yang bisa kita cetak sesuai ukuran yang kita butuhkan. Meskipun media gambar sendiri sebenarnya memiliki banyak kekurangan. Seperti yang disampaikan oleh Susilana (2008, p. 15) media gambar memiliki kelemahan, antara lain: ukurannya terbatas sehingga kurang efektif untuk pembelajaran kelompok besar dan perbandingan yang kurang tepat dari suatu objek akan menimbulkan kesalahan persepsi. Kegiatan pembelajaran yang terjadi bisa dikatakan belum bisa menarik perhatian siswa yang dikarenakan pemanfaatan media masih monoton.

Pemilihan jenis media pembelajaran ternyata berpengaruh terhadap motivasi belajar siswa. Motivasi belajar siswa masih rendah yang terlihat saat siswa kurang antusias saat mengikuti pembelajaran di kelas. Ketika guru menjelaskan materi sekaligus menunjukkan gambar yang terdapat di buku, siswa terlihat kurang bersemangat. Bisa dikatakan bahwa pembelajaran yang hanya memanfaatkan media gambar di buku jelas belum bisa memotivasi siswa untuk belajar. Motivasi belajar yang masih rendah ternyata juga berpengaruh terhadap hasil belajar kognitif siswa. Hasil belajar siswa kelas IV masih perlu ditingkatkan. Rata-rata nilai Ulangan Tengah Semester Genap SD di Gugus Pacarejo masih di bawah Kriteria Ketuntasan Minimal (KKM) yaitu 65, 67. Kondisi yang demikian tentu harus segera diatasi.

Berdasarkan penjelasan di atas, maka perlu dikembangkan suatu media pembelajaran yang mampu memberikan gambaran dengan jelas tentang materi yang dipelajari. Selain itu, pengembangan media video diharapkan mampu mengoptimalkan pemanfaatan fasilitas yang telah tersedia. Media pembelajaran yang dikembangkan dengan memasukkan objek nyata yang ada di lingkungan masyarakat dalam bentuk video untuk menciptakan pembelajaran yang bermakna sehingga mampu meningkatkan motivasi dan hasil belajar kognitif belajar siswa.

\section{Metode}

Model Pengembangan

Model pengembangan diadaptasi dari model pengembangan menurut Borg \& Gall (1983, p.775). Namun penelitian ini hanya dilaksanakan sampai pada tahap ke sembilan, yaitu: (1) penelitian pendahuluan dan pengumpulan informasi, (2) perencanaan, (3) pengembangan draft produk, (4) uji coba awal, (5) merevisi hasil uji coba awal, (6) uji coba lapangan, (7) penyempurnaan produk hasil uji coba lapangan, (8) uji coba operasional, dan (9) penyempurnaan produk akhir.

Desain Uji Coba produk

Uji coba produk terdiri atas tiga tahap yaitu uji coba awal, uji coba lapangan dan uji coba operasional. Sebelum uji coba, produk perangkat pembelajaran ini divalidasi oleh ahli materi dan ahli media kemudian direvisi. Subyek uji coba dalam penelitian ini yaitu: siswa kelas IV Gugus Pacarejo, Kecamatan Semanu, Gunungkidul. Kelas IV SD Jasem sebagai kelas uji coba awal, dengan subyek sebanyak 3 siswa, dan uji coba lapangan sebanyak 9 siswa. kelas IV Jetis sebagai kelas eksperimen dengan jumlah siswa 21 orang dan kelas IV SD Jasem sebagai kelas kontrol sebanyak 19 orang.

Teknik dan Instrumen pengumpulan Data

Teknik pengumpulan data yang digunakan dalam penelitian ini adalah observasi tidak sistematis, wawancara semi terstruktur, skala dengan jenis numerical rating scale, dan tes pilihan ganda. Instrumen yang digunakan pada penelitian dan pengembangan ini adalah pedoman wawancara, skala penilaian produk, skala motivasi belajar, skala respon guru, skala respon siswa, dan tes hasil belajar kognitif.

\section{Teknik Analisis Data}

Analisis data terbagi menjadi dua, yaitu analisis data kualitatif dan kuantitatif. Data kualitatif diperoleh dari data hasil observasi, wawancara, dan komentar serta saran dari ahli materi, media, dan guru. Data yang diperoleh dianalisis dan dideskripsikan secara kualitatif sehubungan dengan pengembangan media video pembelajaran.

Data kuantitatif dalam penelitian dan pengembangan ini berupa skor penilaian ahli, skor motivasi belajar, dan tes hasil belajar kognitif. Data yang dihasilkan dari skala selanjut- 
nya dikelompokkan dengan menggunakan konversi nilai menurut Eko (2015, p.236):

Tabel 1. Kriteria penilaian

\begin{tabular}{|c|c|c|}
\hline Interval skor & Nilai & Kategori \\
\hline $\mathrm{X}>\mathrm{Xi}+1,8 \mathrm{Sbi}$ & $\mathrm{A}$ & Sangat Baik \\
\hline $\begin{array}{c}\mathrm{Xi}+0,6 \times \mathrm{Sbi}<\mathrm{X} \leq \mathrm{Xi}+1,8 \\
\mathrm{Sbi}\end{array}$ & B & Baik \\
\hline $\begin{array}{c}\mathrm{Xi}-0,6 \times \mathrm{Sbi}<\mathrm{X} \leq \mathrm{Xi}+0,6 \\
\mathrm{x} \mathrm{Sbi}\end{array}$ & $\mathrm{C}$ & Cukup Baik \\
\hline $\begin{array}{c}\mathrm{Xi}-1,8 \mathrm{Sbi}<\mathrm{X} \leq \mathrm{Xi}-0,6 \mathrm{x} \\
\mathrm{Sbi}\end{array}$ & D & $\begin{array}{c}\text { Kurang } \\
\text { Baik }\end{array}$ \\
\hline $\mathrm{X} \leq \mathrm{Xi}-1,8 \times \mathrm{Sbi}$ & E & Tidak Baik \\
\hline \multicolumn{3}{|c|}{$\begin{array}{l}\text { Keterangan: } \\
\text { Xi: Mean/ rerata skor ideal }=1 / 2(\text { skor maksimum }+ \\
\text { skor minimun) }\end{array}$} \\
\hline $\begin{array}{l}\text { Sbi : Simpangan Baku ideal = } \\
\quad \text { skor minimum) } \\
\text { X : Skor yang diperoleh }\end{array}$ & & \\
\hline
\end{tabular}

Selanjutnya berdasarkan hasil belajar kognitif, nilai yang diperoleh siswa dihitung menggunakan rumus penilaian sebagai berikut:

$$
\text { Persen skor }=\frac{\text { Jumlah skor perolehan }}{\text { Jumlah skor ideal }} \times 100 \%
$$

Setelah nilai diperoleh, kemudian dibandingkan dengan Kriteria Ketuntasan Minimal (KKM) yaitu 70. Siswa dikatakan tuntas jika memperoleh nilai minimal 70.

\section{Hasil dan Pembahasan}

Studi Pendahuluan

Media video pembelajaran dengan materi kegiatan ekonomi berdasarkan potensi alam ini dikembangkan berdasarkan kebutuhan di lapangan akan suatu media yang mampu memberikan daya tarik siswa untuk belajar serta memberikan kemudahan kepada siswa dalam memahami materi. Pengumpulan informasi dilakukan melalui wawancara, observasi, dan analisis produk yang sudah ada.

Berdasarkan hasil wawancara yang telah dilaksanakan pada bulan Juni 2015 disampaikan bahwa motivasi siswa masih perlu ditingkatkan. Hasil belajar kognitif siswa juga masih di bawah KKM. Hal tersebut sesuai dengan pernyataan guru berikut:

Rd: Motivasi belajar siswa masih rendah. Siswa belum memiliki kemauan tinggi untuk belajar. Padahal saya sudah berusaha mengajar dengan seluruh kemampuan saya, tapi siswa sendiri motivasi belajarnya masih kurang. Hasil belajar siswa juga rendah. Mayoritas siswa mendapatkan nilai di bawah KKM.
Berdasarkan hasil wawancara juga diketahui bahwa guru belum pernah memanfaatkan media video pembelajaran untuk menyampaikan materi kegiatan ekonomi berdasarkan potensi alam pada pembelajaran IPS. Guru hanya memanfaatkan media gambar yang ada pada buku. Berikut salah satu pernyataan guru:

Rd: Saya mengajarkan IPS biasanya memanfaatkan gambar-gambar yang ada di buku. Untuk tambahan saya terkadang mencari gambar-gambar kemudian saya tunjukkan kepada siswa. Kadang juga siswa saya ajak keluar kelas. Untuk video saya belum pernah menggunakannya.

Melalui wawancara juga terungkap bahwa jenis media di sekolah belum lengkap dan masih kesulitan untuk mengembangkan. Berikut pernyataan guru:

Rd: Saya sebenarnya ingin menggunakan berbagai media pembelajaran saat mengajar, namun media pembelajaran yang tersedia masih terbatas. Ada keinginan untuk membuat media tertentu, tapi kami masih kesulitan.

Setiap sekolah sebenarnya sudah diberikan fasilitas guna meningkatkan kualitas pembelajaran, namun pemanfaatannya masih belum maksimal. Seperti yang terjadi di SD Jetis, SD Jasem, dan SD Dengok. Berikut pernyataan salah satu guru:

Rd: Pemanfaatan laptop dan LCD masih jarang digunakan dalam pembelajaran di kelas. LCD biasanya hanya digunakan untuk kegiatan rapat dengan wali murid dan komite atau kegiatan gugus.

Hal tersebut tentu sangat disayangkan, mengingat fasilitas yang ada merupakan sarana bagi guru untuk mampu menciptakan kegiatan yang menarik ternyata belum dimanfaatkan dengan baik. Terkait dengan siswa di kelas IV disampaikan bahwa motivasi belajar masih perlu untuk ditingkatkan. Hasil belajar siswa juga masih rendah. Hal tersebut menjadi tantangan bagi guru untuk mampu menyelesaikan permasalahan tersebut.

Selanjutnya, hasil analisis kebutuhan melalui observasi. Observasi dilakukan untuk memperoleh data tentang media pembelajaran yang digunakan guru saat pembelajaran IPS di kelas IV. Berdasarkan hasil observasi diketahui bahwa saat kegiatan pembelajaran guru hanya menggunakan media pada umumnya, yaitu 
Jurnal Prima Edukasia, 4 (2), Juli 2016 - 214

Titi Suryansyah, Suwarjo

gambar, peta, dan globe. Media yang digunakan kurang bisa menarik perhatian siswa. Pemanfaatan media yang monoton memberikan pengaruh pada motivasi siswa. Siswa terlihat kurang semangat saat mengikuti pembelajaran.

Berdasarkan analisis media sebelumnya, video pembelajaran untuk materi kegiatan ekonomi berdasarkan potensi alam untuk kelas IV sudah ada. Namun, untuk video pembelajaran yang menampilkan kondisi di wilayah Yogyakarta belum ada. Video yang ada banyak menampilkan kondisi wilayah secara keseluruhan se-Indonesia, padahal untuk Standar kompetensi dan Kompetensi dasar di kelas IV masih di lingkup daerahnya yaitu Daerah istimewa Yogyakarta.

Dari hasil analisis kebutuhan tersebut, dapat disimpulkan bahwa guru membutuhkan media pembelajaran yang dapat meningkatkan motivasi dan hasil belajar kognitif. Data yang diperoleh dari studi pendahuluan selanjutnya digunakan untuk merancang suatu media pembelajaran yang menarik bagi siswa.

\section{Data Hasil Penilaian Produk}

Data hasil penilaian produk dilakukan oleh ahli media dan ahli materi. Jumlah skor perolehan berdasarkan ahli materi adalah 66 kategori baik dengan nilai B. Berdasarkan hasil validasi produk oleh ahli media jumlah skor perolehan adalah 65 kategori baik dengan nilai B. Berdasarkan penilaian keseluruhan dari ahli materi dan media, maka media video pembelajaran dinyatakan layak untuk digunakan.

\section{Hasil Uji Coba Awal}

Uji coba awal dilakukan pada 3 orang siswa kelas IV SD Jasem. Ketiga siswa dipilih secara acak dengan mempertimbangkan siswa berkemampuan rendah, sedang, dan tinggi berdasarkan masukan dari guru kelas. Berikut hasil uji coba awal:

\section{Skala Motivasi Belajar}

Berdasarkan hasil uji coba awal diketahui bahwa satu siswa memiliki motivasi belajar baik dan dua siswa yang lain memiliki motivasi sangat baik. Rata-rata motivasi belajar pada uji coba awal adalah 86,67. Berikut hasil skala motivasi dalam bentuk Tabel 2 .
Tabel 2. Hasil Skala Motivasi Belajar Uji Coba Awal

\begin{tabular}{|c|c|c|c|c|}
\hline No & Siswa & Skor & Nilai & Kriteria \\
\hline 1 & NZA & 82 & B & Baik \\
\hline 2 & FZP & 89 & A & Sangat Baik \\
\hline 3 & DNN & 89 & A & Sangat Baik \\
\hline \multicolumn{2}{|c|}{ Jumlah } & 260 & & \\
\hline \multicolumn{2}{|c|}{ Rata-rata } & 86,67 & & \\
\hline \multicolumn{2}{|c|}{ Nilai tertinggi } & 89 & & \\
\hline \multicolumn{2}{|c|}{ Nilai terendah } & 82 & & \\
\hline
\end{tabular}

\section{Tes Hasil Belajar Kognitif}

Kegiatan akhir pada pembelajaran adalah evaluasi hasil siswa. Evaluasi ini bertujuan untuk mengetahui kemampuan siswa berdasarkan materi yang telah dipelajari. Subjek pada uji coba awal ini adalah 3 siswa. Hasil tes belajar kognitif pada uji coba awal seperti pada Tabel 3

Tabel 3. Hasil Belajar Kognitif Siswa Uji Coba Awal

\begin{tabular}{llcc}
\hline No & Siswa & Nilai & Keterangan \\
\hline 1 & NZA & 80 & Tuntas \\
2 & FZP & 80 & Tuntas \\
3 & DNN & 77 & Tuntas \\
\hline & Jumlah & 237 & \\
& Rata-rata & 79 & \\
& Nilai tertinggi & 80 & \\
& Nilai terendah & 77 & \\
\hline
\end{tabular}

Berdasarkan Tabel 3, diketahui bahwa dua siswa memperoleh nilai sama, yaitu 80 . Satu siswa memperoleh nilai 77 . Ketiga siswa sudah tuntas dalam belajar. Rata-rata ketiga nilai siswa adalah 79 .

\section{Skala Respon Guru}

Skala respon oleh guru pada uji coba awal digunakan untuk mengetahui masukan dan saran dari guru tentang media video yang digunakan. Selain itu skala respon guru juga digunakan untuk mengetahui kebermanfaatan penggunaan media video pada pembelajaran. Berikut penilaian respon guru dalam bentuk Tabel 4.

Tabel 4. Penilaian Respon Guru pada Uji Coba Awal

\begin{tabular}{|c|c|c|c|c|}
\hline No & Aspek & Skor & Nilai & Kategori \\
\hline 1 & Materi & 35 & $\mathrm{~A}$ & Sangat Baik \\
\hline 2 & Media & 8 & B & Baik \\
\hline \multicolumn{2}{|c|}{ Total Skor } & 43 & A & Sangat Baik \\
\hline
\end{tabular}

Berdasarkan Tabel 4 mengenai respon guru terhadap keterlaksanaan pembelajaran menggunakan media video sudah berjalan dengan sangat baik. Hal tersebut bisa dilihat pada 
rincian tiap aspek, yaitu aspek materi memperoleh skor 35 dengan nilai A dan aspek media skor 8 dengan nilai $\mathrm{B}$. Total skor dari kedua aspek adalah 43 dengan nilai A. Dari perolehan skor total dapat jika dilihat pada konversi nilai maka masuk kategori sangat baik.

\section{Skala Respon Siswa}

Setelah mengkonversi menjadi skala lima, selanjutnya skor yang diperoleh tiga siswa diolah untuk bisa diketahui nilai dan kriteria menggunakan konversi nilai di atas. Berikut data skala respon siswa pada uji coba awal:

Tabel 5. Hasil Penghitungan Skala Respon Siswa pada Uji Coba Awal

\begin{tabular}{|c|c|c|c|c|}
\hline No & Nama & Skor & Nilai & Kriteria \\
\hline 1 & NZA & 40 & $\mathrm{~A}$ & Sangat Baik \\
\hline 2 & FZP & 37 & B & Baik \\
\hline 3 & DNN & 38 & B & Baik \\
\hline \multicolumn{2}{|c|}{ Jumlah } & 115 & & \\
\hline \multicolumn{2}{|c|}{ Rata-rata } & 38,33 & & \\
\hline \multicolumn{2}{|c|}{ Nilai tertinggi } & 40 & & \\
\hline \multicolumn{2}{|c|}{ Nilai terendah } & 37 & & \\
\hline
\end{tabular}

Berdasarkan hasil respon siswa pada Tabel 5 bisa dilihat bahwa skor rata-rata respon siswa adalah 38,33. Skor tertinggi respon siswa adalah 40 dengan kriteria sangat baik. Skor terendah adalah 37 dengan kriteria baik.

\section{Hasil Uji Coba Lapangan}

Uji coba lapangan dilaksanakan dengan subyek 9 siswa di SD Jasem. Kesembilan siswa diambil secara acak dengan mempertimbangkan kemampuan rendah, sedang, dan tinggi. Data pada uji coba lapangan meliputi skala motivasi belajar siswa, tes hasil belajar kognitif, skala respon guru, dan skala respon siswa. Berikut analisis masing-masing data:

\section{Skala Motivasi Belajar}

Skala motivasi diberikan sebelum dan setelah berakhirnya kegiatan pembelajaran pembelajaran. Berdasarkan hasil motivasi belajar siswa pada uji lapangan diperoleh skor tertinggi adalah 89 dengan kriteria sangat baik dan skor terendah 73 kriteria baik. Rata-rata motivasi belajar siswa pada uji coba lapangan adalah 83 .

\section{Tes Hasil Belajar Kognitif}

Bagian akhir dari kegiatan pembelajaran pada uji lapangan adalah evaluasi. Evaluasi ini diberikan dengan memberikan tes hasil belajar kognitif kepada 9 siswa. Berikut hasil dari evaluasi siswa pada uji lapangan:

Tabel 6. Hasil Belajar Kognitif Siswa Uji Coba Lapangan

\begin{tabular}{llcc}
\hline No & Siswa & Nilai & Keterangan \\
\hline 1 & RTP & 63 & Belum Tuntas \\
2 & IWS & 73 & Tuntas \\
3 & OS & 70 & Tuntas \\
4 & AM & 93 & Tuntas \\
5 & APA & 97 & Tuntas \\
6 & IL & 93 & Tuntas \\
7 & FK & 73 & Tuntas \\
8 & MI & 70 & Tuntas \\
9 & DML & 77 & Tuntas \\
\hline \multicolumn{5}{c}{ Jumlah } & 709 & \\
\multicolumn{7}{c}{ Rata-rata } & 78,78 & \\
Nilai tertinggi & 97 & \\
Nilai terendah & 63 &
\end{tabular}

Berdasarkan Tabel 6 diketahui bahwa rata-rata nilai hasil kognitif siswa adalah 78,78. Perolehan nilai tertinggi hasil belajar kognitif adalah 97 dan nilai terendah diperoleh dengan nilai 63. Kriteria Ketuntasan Minimal yang diharapkan adalah 70, oleh karena itu ada satu siswa dengan perolehan nilai 63 yang belum tuntas dalam kegiatan uji coba lapangan.

\section{Skala Respon Guru}

Di bawah ini data respon guru saat uji lapangan yang kemudian dikonversikan ke skala lima:

Tabel 7. Penilaian Skala Respon Guru pada Uji Coba Lapangan

\begin{tabular}{|c|c|c|c|c|}
\hline No & Aspek & Skor & Nilai & Kategori \\
\hline 1 & Materi & 35 & $\mathrm{~A}$ & Sangat baik \\
\hline 2 & Media & 10 & A & Sangat Baik \\
\hline \multicolumn{2}{|c|}{ Total Skor } & 45 & $\mathrm{~A}$ & Sangat Baik \\
\hline
\end{tabular}

Berdasarkan Tabel 7 mengenai respon guru terhadap keterlaksanaan pembelajaran menggunakan media video pada uji coba lapangan sudah berjalan dengan sangat baik. Hal tersebut bisa dilihat pada rincian tiap aspek, yaitu aspek materi memperoleh skor 35 dengan nilai A dan aspek media skor 10 dengan nilai $\mathrm{A}$. Total skor dari kedua aspek adalah 45 dengan nilai A. Dari perolehan skor total dapat jika dilihat pada konversi nilai maka masuk kategori sangat baik.

\section{Skala Respon Siswa}

Skala respon siswa terdiri atas dua aspek seperti respon siswa saat uji coba awal. Skala respon siswa diberikan kepada 9 siswa yang 
menjadi subyek dalam uji coba lapangan. Skala ini diberikan untuk mengetahui respon siswa terhadap penggunaan media video saat kegiatan pembelajaran. Data hasil respon siswa kemudian diolah menggunakan dasar konversi penilaian skala respon siswa.

Berdasarkan tabel tersebut bisa disimpulkan bahwa terdapat 2 siswa yang memberikan respon dengan nilai baik. Selain itu, ada 7 siswa yang memberikan respon sangat baik terhadap penggunaan media video dalam kegiatan pembelajaran. Berdasarkan uji lapangan, dapat diketahui adanya respon positif terhadap pemanfaatan media video dalam pembelajaran.

Tabel 8. Penghitungan Skala Respon Siswa pada Uji Coba Lapangan

\begin{tabular}{|c|c|c|c|c|}
\hline No & Nama & Skor & Nilai & Kriteria \\
\hline 1 & RTP & 40 & $\mathrm{~A}$ & Sangat Baik \\
\hline 2 & IWS & 38 & B & Baik \\
\hline 3 & OS & 39 & A & Sangat Baik \\
\hline 4 & AM & 38 & B & Baik \\
\hline 5 & APA & 41 & A & Sangat Baik \\
\hline 6 & IL & 40 & A & Sangat Baik \\
\hline 7 & FK & 42 & A & Sangat Baik \\
\hline 8 & MI & 40 & A & Sangat Baik \\
\hline 9 & DML & 41 & A & Sangat Baik \\
\hline \multicolumn{2}{|c|}{ Jumlah } & 359 & & \\
\hline \multicolumn{2}{|c|}{ Rata-rata } & 39,87 & & \\
\hline \multicolumn{2}{|c|}{ Nilai tertinggi } & 42 & & \\
\hline \multicolumn{2}{|c|}{ Nilai terendah } & 38 & & \\
\hline
\end{tabular}

\section{Hasil Uji Coba Operasional}

Setelah produk diujicobakan awal dan lapangan, sesuai dalam langkah penelitian pengembangan menurut Borg \& Gall adalah diujicobakan operasional. Uji coba ini akan melibatkan dua kelas dalam dua sekolah dimana satu kelas sebagai eksperimen dan satu kelas sebagai kontrol. Sekolah yang digunakan sebagai eksperimen adalah SD Jetis dengan 21 siswa. Sekolah yang digunakan sebagai kelas kontrol adalah SD Dengok dengan 19 siswa. Pada tahap uji coba operasional data yang berupa motivasi belajar, hasil belajar kognitif, respon guru dan reson siswa akan dikumpulkan. Berikut ini analisis dari masing-masing data:

\section{Skala Motivasi Belajar}

Motivasi belajar siswa menjadi salah satu fokus penelitian ini. Penilaian skala motivasi belajar didasarkan pada meningkat atau tidaknya motivasi belajar siswa setelah mengikuti kegiatan pembelajaran menggunakan media video pada kelas eksperimen.
Berikut ini adalah rekapan hasil penilaian skala motivasi awal siswa kelas kontrol dan kelas eksperimen.

Tabel 9. Hasil Penilaian Skala Motivasi Awal

\begin{tabular}{|c|c|c|c|c|}
\hline \multirow[b]{2}{*}{ No } & \multirow{2}{*}{$\begin{array}{c}\text { Hasil } \\
\text { Penilaian }\end{array}$} & \multirow[b]{2}{*}{ Kategori } & \multicolumn{2}{|c|}{ Jumlah Siswa } \\
\hline & & & $\begin{array}{c}\text { K. } \\
\text { Kontrol }\end{array}$ & $\begin{array}{c}\text { K. } \\
\text { Eksperimen }\end{array}$ \\
\hline 1 & $X>84$ & $\begin{array}{c}\text { Sangat } \\
\text { Baik }\end{array}$ & 0 & 0 \\
\hline 2 & $\begin{array}{l}68<X \leq \\
84\end{array}$ & Baik & 15 & 15 \\
\hline 3 & $\begin{array}{l}52<X \leq \\
68\end{array}$ & $\begin{array}{c}\text { Cukup } \\
\text { baik }\end{array}$ & 4 & 6 \\
\hline 4 & $\begin{array}{l}36<X \leq \\
52\end{array}$ & $\begin{array}{c}\text { Kurang } \\
\text { Baik }\end{array}$ & 0 & 0 \\
\hline 5 & $X \leq 36$ & $\begin{array}{c}\text { Tidak } \\
\text { baik }\end{array}$ & 0 & 0 \\
\hline & Jumlah & & 19 & 21 \\
\hline
\end{tabular}

Berdasarkan Tabel 9 dapat dilihat bahwa pada kelas kontrol dari 19 siswa terdapat 4 siswa yang mendapatkan nilai $\mathrm{C}$ dengan kategori cukup baik dan 15 siswa mendapatkan nilai B dengan kategori baik. Selain itu, pada kelas eksperimen terdapat 6 siswa yang memperoleh nilai $\mathrm{C}$ dengan kriteria cukup baik dan 15 siswa memperoleh nilai $\mathrm{B}$ dengan kriteria baik. Secara keseluruhan bisa disimpulkan bawah perolehan nilai belum sepenuhnya baik.

Selanjutnya, berikut rekapan hasil motivasi belajar akhir setelah selesai mengikuti pembelajaran di kelas kontrol dan kelas eksperimen:

Tabel 10. Hasil Penilaian Skala Motivasi

\begin{tabular}{ccccc}
\hline No & $\begin{array}{c}\text { Hasil } \\
\text { Penilaian }\end{array}$ & Kategori & \multicolumn{2}{c}{ Jumlah Siswa } \\
\cline { 3 - 5 } & $\begin{array}{c}\text { K. } \\
\text { Kontrol }\end{array}$ & $\begin{array}{c}\text { K. } \\
\text { Eksperimen }\end{array}$ \\
\hline 1 & $\mathrm{X}>84$ & $\begin{array}{c}\text { Sangat } \\
\text { Baik }\end{array}$ & 4 & 12 \\
2 & $68<\mathrm{X} \leq$ & $\begin{array}{c}\text { Baik } \\
84\end{array}$ & 14 & 9 \\
3 & $\begin{array}{c}52<\mathrm{X} \leq \\
68\end{array}$ & $\begin{array}{c}\text { Cukup } \\
\text { baik }\end{array}$ & 1 & 0 \\
4 & $\begin{array}{c}36<\mathrm{X} \leq \\
52\end{array}$ & $\begin{array}{c}\text { Kurang } \\
\text { Baik }\end{array}$ & 0 & 0 \\
5 & $\mathrm{X} \leq 36$ & $\begin{array}{c}\text { Tidak } \\
\text { baik }\end{array}$ & 0 & 0 \\
\hline \multicolumn{2}{c}{ Jumlah } & & 19 & 21 \\
\hline
\end{tabular}

Berdasarkan Tabel 10, terlihat bahwa pada kelas kontrol terdapat 4 siswa yang mendapatkan nilai A dengan kategori sangat baik. Masih di kelas kontrol, terdapat 14 siswa yang mendapatkan nilai $\mathrm{B}$ dengan kategori baik dan 1 siswa masih mendapatkan nilai $\mathrm{C}$ dengan kriteria cukup baik. Pada kelas eksperimen 
terlihat bahwa 12 mendapatkan nilai A dengan kategori sangat baik dan 9 siswa berada pada kategori baik dengan nilai B. Selain dalam bentuk Tabel, berikut disajikan data motivasi belajar siswa dalam bentuk diagram:

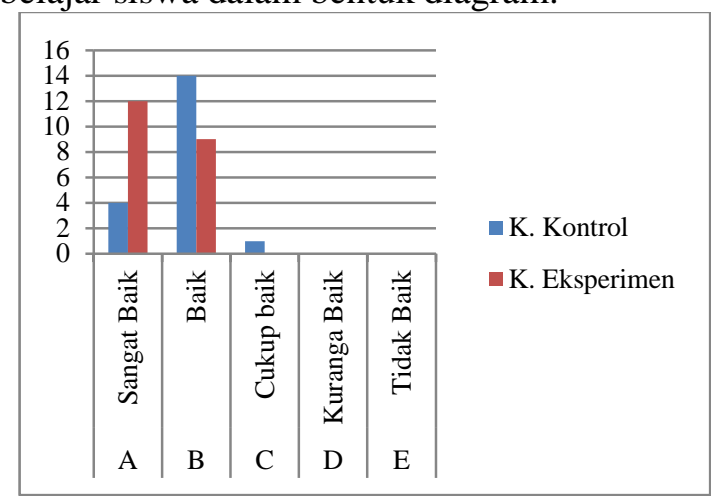

Gambar 1. Hasil Motivasi Belajar pada Uji Coba Operasional

\section{Tes Hasil Belajar Kognitif}

Hasil belajar kognitif menjadi salah satu fokus peningkatan sehubungan dengan pengembangan media video pembelajaran. Berdasarkan hasil data selama uji coba operasional didapatkan data hasil belajar pretest dan posttest. Pada kelas kontrol dan kelas eksperimen hasil pretest semua siswa belum mencapai KKM. Hasil pretest pada kelas kontrol dan eksperimen bisa dilihat pada Tabel 11.

Tabel 11. Hasil Rekapan Pretest Hasil Belajar Kognitif

\begin{tabular}{cccc}
\hline \multirow{2}{*}{ No } & \multirow{2}{*}{$\begin{array}{c}\text { Kategori } \\
\text { KKM 70) }\end{array}$} & \multicolumn{2}{c}{ Jumlah Siswa } \\
\cline { 3 - 4 } & Kontrol & $\begin{array}{c}\text { K. } \\
\text { Eksperimen }\end{array}$ \\
\hline 1 & Tuntas & 0 & 0 \\
2 & Tidak Tuntas & 19 & 21 \\
\hline \multirow{2}{*}{ Jumlah } & 887 & 978 \\
& Rata-rata & 46,68 & 46,57 \\
& Nilai Tertinggi & 63 & 63 \\
& Nilai Terendah & 33 & 30 \\
\hline
\end{tabular}

Nilai tertinggi siswa hanya 63 , sedangkan nilai terendah 33. Rata-rata perolehan nilai hanya 46,68 . Hasil yang demikian tentu masih jauh dari harapan. Selain itu, dari Tabel 11 diketahui bahwa semua siswa pada kelas eksperimen belum ada yang memperoleh nilai di atas KKM. Nilai tertinggi yang bisa diraih masih sama dengan kelas kontrol, yaitu 63 . Nilai terendah adalah 30 dan rata-rata dalam satu kelas adalah 46,57. Rata-rata di kelas eksperimen ini masih di bawah selisih sedikit dengan rata-rata hasil belajar siswa di kelas kontrol.
Pada kelas eksperimen, guru memberikan pembelajaran menggunakan media video yang telah dikembangkan. Setelah materi tentang kegiatan ekonomi berdasarkan potensi alam selesai, guru memberikan posttest keada siswa untuk mengetahui sejauh mana kemampuan siswa terhadap materi tersebut. Berikut rekapan hasil posttest di kelas kontrol dan eksperimen:

Tabel 12. Hasil Rekapan Posttest Hasil belajar Kognitif

\begin{tabular}{cccc}
\hline \multirow{2}{*}{ No } & \multirow{2}{*}{$\begin{array}{c}\text { Kategori } \\
\text { (KKM 70) }\end{array}$} & $\begin{array}{c}\text { Kumlah Siswa } \\
\text { Kontrol }\end{array}$ & $\begin{array}{c}\text { K. } \\
\text { Eksperimen }\end{array}$ \\
\cline { 3 - 4 } & & 17 & 21 \\
2 & Tuntas & 2 & 0 \\
& Tidak Tuntas & 1397 & 1723 \\
\hline \multirow{2}{*}{ Jumlah } & Rata-rata & 73,53 & 82,05 \\
Nilai Tertinggi & 93 & 97 \\
Nilai Terendah & 67 & 70 \\
\hline
\end{tabular}

Berdasarkan hasil posttest di kelas kontrol dan eksperimen diketahui mengalami peningkatan dari hasil pretest. Pada kelas kontrol nilai tertinggi yang bisa diraih siswa adalah 93 . Nilai terendah adalah 67 dan nilai rata-rata adalah 73,53. Berdasarkan hasil yang ada diketahui masih ada 2 siswa yang belum tuntas belajarnya karena nilai masih di bawah 70. Selanjutnya, untuk kelas eksperimen nilai tertinggi yang diperoleh siswa adalah 97 dan nilai terendah adalah 70. Rata-rata nilai posttest adalah 82,05. Semua siswa pada kelas eksperimen memperoleh nilai di atas 70 yang berarti sudah memenuhi KKM. Berikut rekapan hasil belajar kognitif yang ditunjukkan dalam bentuk diagram:

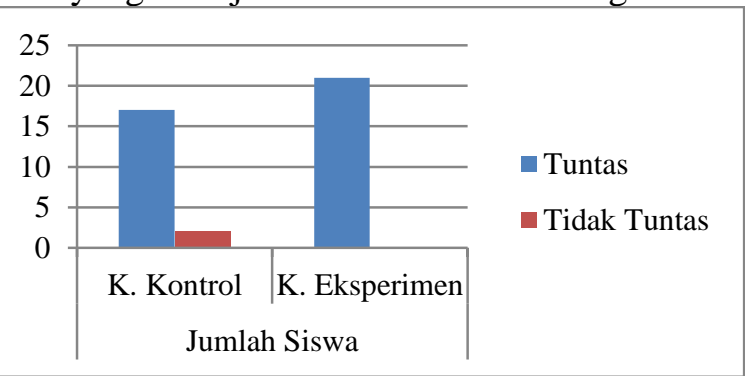

Gambar 2. Penilaian Hasil belajar Kognitif pada Uji Coba Operasional

Dari rata-rata prettest siswa di dua kelas yang hampir sama, sudah bisa menjelaskan bahwa kemampuan awal siswa pada dua kelas, yaitu kelas kontrol dan kelas eksperimen adalah hampir sama. Sedangkan, untuk hasil posttest siswa di kelas kontrol dan kelas eksperimen jauh berbeda. Rata-rata nilai posttest di kelas eksperimen jauh lebih tinggi dibandingkan ratarata nilai posttest di kelas kontrol. 
Jurnal Prima Edukasia, 4 (2), Juli 2016 - 218

Titi Suryansyah, Suwarjo

\section{Skala Respon Guru}

Pada uji coba operasional ada dua kelas yang dilibatkan, yaitu kelas kontrol dan kelas eksperimen. Meskipun dua kelas yang dilibatkan, namun hanya kelas eksperimen saja yang memanfaatkan media video yang dikembangkan dalam kegiatan pembelajarannya.

Tabel 13. Penilaian Skala Respon Guru pada Uji Coba Operasional

\begin{tabular}{|c|c|c|c|c|}
\hline No & Aspek & Skor & Nilai & Kategori \\
\hline 1 & Materi & 35 & A & Sangat Baik \\
\hline 2 & Media & 9 & A & Sangat Baik \\
\hline \multicolumn{2}{|c|}{ Total Skor } & 44 & A & Sangat Baik \\
\hline
\end{tabular}

Berdasarkan Tabel 13 tentang respon guru terhadap penggunaan media video dan keterlaksanaan kegiatan pembelajaran dengan media video dapat dibaca bahwa aspek materi mendapatkan skor 35 dengan nilai A kategori sangat baik dan aspek media memperoleh skor 9 dengan nilai A kategori sangat baik. Total skor pada respon guru adalah 44 dengan nilai $\mathrm{A}$ kategori sangat baik. Berdasarkan hasil respon guru di atas dapat disimpulkan bahwa guru memberikan respon sangat positif terhadap media sebagai penunjang kegiatan pembelajaran. Berikut hasil respon guru pada uji coba operasional dalam bentuk diagram:

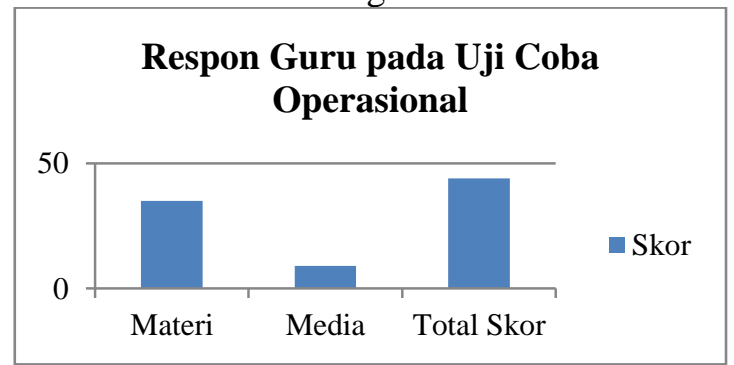

Gambar 3. Hasil Respon Guru pada Uji Coba Operasional

\section{Skala Respon Siswa}

Selain meminta respon terhadap guru atas keterlaksanaan pembelajaran, respon siswa juga dilakukan guna mengetahui sejauh mana tanggapan siswa terhadap pemanfaatan media video dalam pembelajaran. Respon siswa terdiri atas dua aspek, yaitu aspek materi dan media. Kedua aspek terdiri atas beberapa indikator yang mencakup kedua aspek tersebut. Berikut hasil rekapan respon siswa terhadap media video yang telah digunakan saat pembelajaran:
Tabel 14. Hasil Penghitungan Skala Respon Siswa pada Uji Coba Operasional

\begin{tabular}{|c|c|c|c|c|}
\hline No & Nama & Skor & Nilai & Kriteria \\
\hline 1 & $\mathrm{BSN}$ & 39 & $\mathrm{~A}$ & Sangat Baik \\
\hline 2 & RDL & 38 & B & Baik \\
\hline 3 & $\mathrm{M}$ & 43 & A & Sangat Baik \\
\hline 4 & PR & 45 & A & Sangat Baik \\
\hline 5 & BS & 39 & A & Sangat Baik \\
\hline 6 & ANH & 40 & A & Sangat Baik \\
\hline 7 & PSW & 42 & A & Sangat Baik \\
\hline 8 & $\mathrm{BP}$ & 40 & A & Sangat Baik \\
\hline 9 & AJS & 41 & A & Sangat Baik \\
\hline 10 & $\mathrm{DM}$ & 42 & A & Sangat Baik \\
\hline 11 & IU & 42 & A & Sangat Baik \\
\hline 12 & SAN & 42 & A & Sangat Baik \\
\hline 13 & TNR & 42 & A & Sangat Baik \\
\hline 14 & DS & 40 & A & Sangat Baik \\
\hline 15 & LVK & 42 & A & Sangat Baik \\
\hline 16 & IM & 41 & A & Sangat Baik \\
\hline 17 & LAIP & 37 & B & Baik \\
\hline 18 & DPR & 41 & A & Sangat Baik \\
\hline 19 & AR & 41 & A & Sangat Baik \\
\hline 20 & ND & 39 & A & Sangat Baik \\
\hline 21 & EDA & 39 & A & Sangat Baik \\
\hline \multicolumn{2}{|c|}{ Jumlah } & 376 & & \\
\hline \multicolumn{2}{|c|}{ Rata-rata } & 41,78 & & \\
\hline \multicolumn{2}{|c|}{ Nilai tertinggi } & 44 & & \\
\hline \multicolumn{2}{|c|}{ Nilai terendah } & 39 & & \\
\hline
\end{tabular}

Berdasarkan Tabel 14 tentang respon siswa terhadap pemanfaatan media video saat pembelajaran mendapatkan respon yang sangat baik. Nilai A dengan kriteria sangat baik diberikan oleh 19 siswa. Selain itu ada dua siswa yang memberikan nilai $\mathrm{B}$ dengan kriteria baik. Hasil respon siswa terhadap penggunaan media video dalam bentuk diagram dapat dilihat dalam Gambar 4.

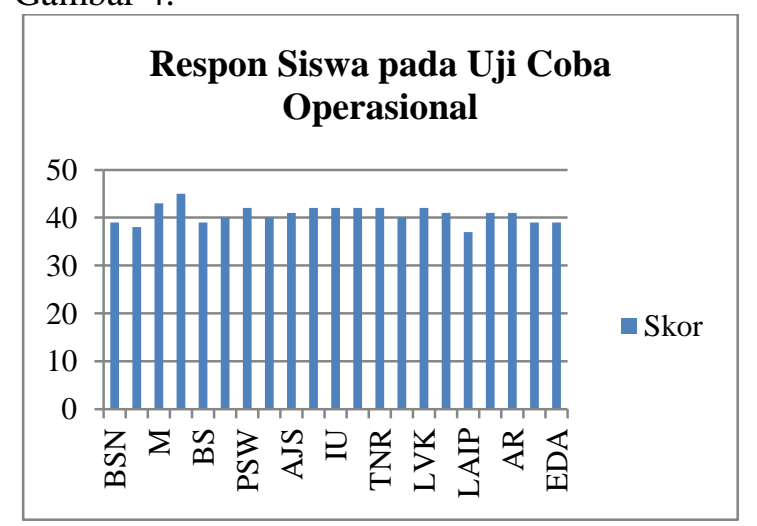

Gambar 4. Hasil Respon Siswa pada Uji Coba Operasional

Pembahasan

Data hasil uji kelayakan produk media video pembelajaran diperoleh dari hasil validasi yang dilakukan oleh ahli media dan ahli materi. 
Jurnal Prima Edukasia, 4 (2), Juli 2016 - 219

Titi Suryansyah, Suwarjo

Penilaian ahli dikonversikan menjadi skala lima dan hasil skor yang diperoleh bisa ditentukan kriteria penilaiannya menggunakan panduan penskoran. Produk media video pembelajaran dibuat sesuai dengan aspek pengembangan media pembelajaran.

Terdapat dua aspek pengembangan media yang digunakan sebagai acuan, yaitu materi dan media. Aspek materi terdiri atas 4 indikator, yaitu ketepatan materi, keluasan materi, kejelasan materi, dan kemenarikan materi yang disajikan. Keempat indikator pada aspek materi akan digunakan sebagai penyusunan instrumen penilaian ahli materi. Aspek media terdiri atas 2 indikator, yaitu kualitas isi video dan kualitas teknis. Kedua indikator pada aspek media akan digunakan sebagai penyusunan instrumen penilaian ahli media.

Setelah media video dibuat, langkah selanjutnya adalah menilaikan produk tersebut kepada ahli. Ahli yang dilibatkan disini meliputi ahli media dan ahli materi pembelajaran. Data hasil penilaian oleh ahli media dikonversikan menjadi skala lima. Produk media video dikatakan layak digunakan jika minimal berada pada kategori baik.

Berdasarkan hasil validasi produk oleh ahli materi dapat dijelaskan bahwa pada indikator ketepatan materi memperoleh skor 25 dengan kategori baik, keluasan materi mendapatkan skor 11 kategori baik, kejelasan materi memperoleh skor 18 kategori sangat baik, kemenarikan materi memperoleh skor 12 dengan kategori baik. Jumlah skor perolehan berdasarkan ahli materi adalah 66 kategori baik dengan nilai B. Berdasarkan ahli materi dinyatakan bahwa produk yang dikembangkan layak untuk digunakan.

Berdasarkan hasil validasi produk oleh ahli media dapat dijelaskan bahwa pada indikator kualitas isi video memperoleh skor 29 yang mendapatkan nilai B dengan kategori baik. Indikator kualitas teknis mendapatkan skor 36 dengan nilai $\mathrm{B}$ berada pada kategori baik. Jumlah skor perolehan berdasarkan ahli media adalah 65 kategori baik dengan nilai B. Berdasarkan penilaian keseluruhan dari ahli media, maka media video pembelajaran dinyatakan layak untuk digunakan.

Data keefektifan dilihat dari hasil motivasi dan hasil belajar kognitif siswa yang diberikan setelah mengikuti kegiatan pembelajaran menggunakan media video yang dikembangkan. Berdasarkan hasil analisis data diperoleh bahwa ada perbedaan signifikan antara motivasi belajar dan hasil belajar kognitif siswa yang menggunakan dan tidak menggunakan media video pembelajaran.

Berdasarkan hasil uji paired sample t test diperoleh bahwa ada perbedaan skor motivasi belajar antara sebelum dan sesudah menggunakan media video pembelajaran. Hasil belajar kognitif siswa juga menunjukkan hal yang sama, yaitu adanya perbedaan hasil antara sebelum dan sesudah pembelajaran menggunakan media video. Hasil pengujian tersebut senada dengan yang disampaikan oleh Arends \& Kilcher (2010, p. 225) "Instead, we will argue that the proper use of video, television, and film can promote visual literacy and become important resources for helping students asquire new information and background knowledge on a wide variety of topics". Penjelasan tersebut dapat disimpulkan bahwa video menjadi salah satu sumber penting dalam memberikan informasi atau pengetahuan yang belum dipahami oleh siswa. Video mampu memberikan informasi yang dapat diamati secara langsung oleh siswa. Hasil pengamatan siswa akan menambah pengetahuannya. Informasi yang diperoleh dari hasil pengamatan video juga semakin memperkuat video dapat meningkatkan hasil belajar kognitif siswa.

Video pembelajaran merupakan bentuk media yang mampu menjembatani guru supaya pembelajaran tidak bersifat konvensional. Kemenarikan media yang dikembangkan memberikan daya tarik pada siswa, karena dalam video terdapat alunan musik, suara dan ilustrasi penjelas, serta gambar yang diambil dari kondisi nyata yang dikemas menarik. Hal tersebut sesuai dengan pendapat Woolfolk (2009, p. 59) yang menyatakan bahwa pembelajaran untuk anak pada tahap operasional konkret bisa dilakukan dengan menggunakan alat bantu visual serta melibatkan hal-hal yang bersifat konkret. Video pembelajaran yang dikembangkan mampu menampilkan objek-objek nyata sehingga sesuai dengan siswa kelas IV SD. Pemilihan musik juga disesuaikan dengan karakteristik siswa SD. Hal tersebut disesuaikan dari saran ahli media pada penelitian pengembangan oleh Fredy \& Soenarto (2013, p.169) bahwa musik pembuka pada media disesuaikan dengan karakteristik siswa SD. Berdasar pada saran tersebut, maka media video ini menggunakan musik acara anak sebagai iringan musiknya. 
Jurnal Prima Edukasia, 4 (2), Juli 2016 - 220

Titi Suryansyah, Suwarjo

\section{Simpulan dan Saran}

Berdasarkan penelitian yang telah dilaksanakan, dapat disimpulkan bahwa: (1) Produk media video pembelajaran materi kegiatan ekonomi berdasarkan potensi alam yang dikembangkan untuk meningkatkan motivasi dan hasil belajar kognitif siswa dinyatakan layak digunakan dalam pembelajaran menurut ahli media dengan nilai baik. (2) Produk media video pembelajaran materi kegiatan ekonomi berdasarkan potensi alam yang dikembangkan untuk meningkatkan motivasi dan hasil belajar kognitif siswa dinyatakan layak digunakan dalam pembelajaran menurut ahli materi dengan nilai baik. (3) Produk media video pembelajaran materi kegiatan ekonomi berdasarkan potensi alam terbukti efektif untuk meningkatkan motivasi belajar siswa kelas IV SD. Hal ini terbukti dari data uji coba operasional di kelas kontrol dan eksperimen setelah dilakukan uji $\mathrm{t}$ terbukti ada perbedaan signifikan dalam hal motivasi belajar siswa antara kelas yang menggunakan media video dan yang tidak menggunakan media video. (4) Produk media video pembelajaran materi kegiatan ekonomi berdasarkan potensi alam terbukti efektif untuk meningkatkan hasil belajar kognitif siswa kelas IV SD. Hal ini terbukti dari data uji coba operasional di kelas kontrol dan eksperimen setelah dilakukan uji t terbukti ada perbedaan signifikan dalam hal hasil belajar kogntifi siswa pada kelas yang menggunakan media video dengan yang tidak menggunakan media video.

Berdasarkan simpulan mengenai pengembangan media video ini, maka disarankan kepada guru untuk menggunakan produk video ini sebagai alternatif media dalam pembelajaran khususnya untuk meningkatkan motivasi dan hasil belajar kognitif siswa.

\section{Daftar Pustaka}

Arends, R. I. \& Kilcher, A. (2010). Teaching for student learning. New York and London: Routledge

Astuti, Y., \& Mustadi, A. (2014). Pengaruh penggunaan media film animasi terhadap keterampilan menulis karangan narasi siswa kelas V SD.. Jurnal Prima Edukasia, 2(2), 250-262. Retrieved from http://journal.uny.ac.id/index.php/jpe/arti cle/view/2723

Bavaharji, M., Alavi, Z. K., \& Letchumanan, K. (2014). Captioned instructional video: effects on content comprehension vocabulary acquisition and language proficiency. Canadian Center of Science and Education, 7, 1-16

Borg, W. R., \& Gall, M.D. (1983). Educational research. New York: Longman Inc

Fredy, F., \& Soenarto, S. (2013). Pengembangan multimedia pembelajaran matematika pada materi bilangan bulat kelas IV SDN Lempuyangan 1 Yogyakarta. Jurnal Prima Edukasia, l(2), 162-172. Retrieved from http://journal.uny.ac.id/index.php/jpe/arti cle/view/2633/2188

Indaryati, I., \& Jailani, J. (2015). Pengembangan media komik pembelajaran matematika meningkatkan motivasi dan prestasi belajar siswa kelas V. Jurnal Prima Edukasia, 3(1), 84-96. Retrieved from http://journal.uny.ac.id/index.php/jpe/arti cle/view/4067/3521

Li. Y. J. \& Shieh. J. C. (2015). A study on the effects of multiple goal orientation on learning motivation and learning behaviors. Eurasia Journal of Mathematics, Science \& Technology Education, 12(1), 161-172

Muvawala, J. (2012). Determinants of learning outcomes for primary education: A case of Uganda. Journal Statistique Africain. 15. $42-54$

Santrock, J. W. (2011). Psikologi pendidikan. Jakarta : Kencana

Schunk, D. H. (2012). Learning theories. Jakarta: Pustaka Pelajar

Sonmez, D. \& Can, M. H. (2012). Videos as an instructional tool in pre service science teacher education. Eurasian Journal of Education Research, 46, 141-158

Susilana, R. (2008). Media pembelajaran. Bandung: Universitas Pendidikan Indonesia

Widoyoko, E. P. (2015). Evaluasi program pembelajaran. Yogyakarta: Pustaka Pelajar

Woo, C. J. (2014). Digital game based learning support student motivation, cognitive success, and performance outcomes. 
Jurnal Prima Edukasia, 4 (2), Juli 2016 - 221

Titi Suryansyah, Suwarjo

Educational Technology \& Society, 17, 291-307

Woolfolk, A. (2009). Educational psychology active learning edition. Boston: Pearson Education, Inc
Yoon, O. J. \& Kim. M. (2011). The effects of captions on deaf students content comprehension, cognitive load, and motivation in online learning. American Annual of The Deaf, 156(3), 283-289 